\title{
Fukushima as Australia's nuclear heritage
}

\author{
N. A. J. Taylor \\ Alfred Deakin Postdoctoral Research Fellow, Deakin University, Australia \\ Correspondence: N. A. J. Taylor (hi@ najtaylor.com) \\ Published: 10 November 2021
}

\begin{abstract}
On 11 March 2011 a 9.0 magnitude earthquake and resultant tsunami caused a full meltdown of the Fukushima Daiichi nuclear power plant located on the island of Honshu, on the east coast of Japan. It took 4 weeks for the radionuclides to circumnavigate the Earth and descend into the Southern hemisphere. Although scholarly activity has continued apace in relation to different aspects of Fukushima as an event and site, very little of this work has examined the implications of Australian uranium being found inside several of Fukushima Daiichi's reactors at the time of the disaster. This paper explores Fukushima as a central, yet heretofore neglected, artefact of Australia's cultural and environmental heritage.
\end{abstract}

Kurzfassung. Am 11. März 2011 verursachten ein Erdbeben der Stärke 9,0 und ein darauffolgender Tsunami eine vollständige Kernschmelze im Kernkraftwerk Fukushima Daiichi auf der Insel Honshu an der Ostküste Japans. Es dauerte 4 Wochen, bis die Radionuklide die Erde umrundet hatten und in die südliche Hemisphäre abgesunken waren. Obwohl sich die Wissenschaft zügig mit verschiedenen Aspekten des Ereignisses und des Standorts Fukushima befasst hat, wurden die Auswirkungen des australischen Urans, das zum Zeitpunkt der Katastrophe in mehreren Reaktoren von Fukushima Daiichi gefunden wurde, nur in sehr wenigen Arbeiten untersucht. Dieser Beitrag untersucht Fukushima als ein zentrales, aber bisher vernachlässigtes Artefakt des australischen Kultur- und Umwelterbes. 